\title{
Habitat use and demographic population structure of elasmobranchs at a Caribbean atoll (Glover's Reef, Belize)
}

\author{
Ellen K. Pikitch ${ }^{1,4, *}$, Demian D. Chapman ${ }^{2,4}$, Elizabeth A. Babcock ${ }^{3,4}$, Mahmood S. Shivji ${ }^{2}$ \\ ${ }^{1}$ Pew Institute for Ocean Science, Rosenstiel School of Marine and Atmospheric Science, University of Miami, \\ 126 East 56th Street, New York, New York 10022, USA \\ ${ }^{2}$ Guy Harvey Research Institute/Nova Southeastern University Oceanographic Center, Dania Beach, Florida 33004, USA \\ ${ }^{3}$ Pew Institute for Ocean Science, Rosenstiel School of Marine and Atmospheric Science, University of Miami, \\ 4600 Rickenbacker Causeway, Miami, Florida 33149, USA \\ ${ }^{4}$ Wildlife Conservation Society, 2300 Southern Boulevard, Bronx, New York 10460, USA
}

\begin{abstract}
A 5 yr spring and summer survey (July 2000 to May 2004) of the elasmobranch fauna of Glover's Reef Marine Reserve, Belize, documents the use of this oceanic atoll by at least 12 elasmobranch species, including early life-stages of nurse sharks Ginglymostoma cirratum, Caribbean reef sharks Carcharhinus perezi, lemon sharks Negaprion brevirostris, and southern stingrays Dasyatis americana. Elasmobranch abundance was sampled in 3 atoll macrohabitats (deep lagoon, ocean reef, shallow lagoon) using standardized longlines. Total elasmobranch abundance did not change from year to year, but was significantly higher inside the lagoon than on the ocean reef outside the atoll. G. cirratum dominated both shallow and deep lagoon catches, with smaller individuals more prevalent in the shallow lagoon. C. perezi of all size classes dominated the ocean reef catches, but small juveniles of this species were also common in the deep lagoon. This species rarely utilized the shallow lagoon. A wide range of sizes of $C$. perezi and G. cirratum occupy Glover's Reef in spring and summer, with males maturing at 150 to $170 \mathrm{~cm}$ and 185 to $200 \mathrm{~cm}$ total length, respectively. The sex ratios of these species did not deviate from unity. A large juvenile Galápagos shark, C. galapagensis, was collected on the ocean reef, extending the range of this species into the Western Caribbean. Opportunistic surveys of fish markets on the Belize mainland revealed that inshore areas are utilized by early life-stages of sharks from the families Carcharhinidae (C. limbatus, $N$. brevirostris, Rhizoprionodon porosus) and Sphyrnidae (Sphyrna tiburo, S. lewini, S. mokarran).
\end{abstract}

KEY WORDS: Shark · Batoid · Habitat partitioning $\cdot$ Marine reserve $\cdot$ Mesoamerican Barrier Reef Resale or republication not permitted without written consent of the publisher

\section{INTRODUCTION}

Very little is known about the diversity, natural history and conservation status of elasmobranchs along the Caribbean coast of Central America, including those which inhabit the Mesoamerican Barrier Reef, the second largest barrier reef in the world. Glover's Reef is a remote oceanic atoll, which, along with 2 other atolls (Turneffe and Lighthouse Reef), forms an offshore component of the barrier reef ecosystem (Gibson 2003). Already a United Nations World Her- itage Site, this atoll was further targeted for conservation in 1993 by the designation of the Glover's Reef Marine Reserve (GRMR). Although there have been published scientific investigations of some components of this protected ecosystem (Acosta 2001, 2002, Acosta \& Robertson 2003, McClanahan et al. 2003), almost nothing was known about its elasmobranch fauna until the present study began in 2000. In general, the diversity, demographic population structure and habitat use patterns of the sharks and rays that inhabit Caribbean coral reefs are not as well understood as those of 
elasmobranch assemblages of Pacific coral reefs (Johnson 1978, McKibben \& Nelson 1986, Tricas 1987).

Habitat use by elasmobranchs is a topic of current and increasing research interest, in part because recent studies have started to reveal the important role these top-level predators may play in structuring marine communities (Stevens et al. 2000, Heithaus et al. 2002, Heithaus 2004, Bascompte et al. 2005). For example, a recently constructed, quantitative, ecosystem model of a Caribbean coral reef food web suggests that sharks regulate the population size of large piscivorous fishes, which in turn control populations of herbivorous fishes that graze algae (Bascompte et al. 2005). This model suggested that the overfishing of sharks has contributed to the shift from coral- to algaldominated reefs in the region (Bascompte et al. 2005). Although our understanding of the ecological role of reef-associated sharks in the Caribbean is still in its infancy, an important first step towards understanding their ecology is to determine species-specific patterns of habitat use.

Recent studies have focused on characterizing the habitats used by juvenile sharks because of the importance of juvenile survival in the demographics of these $K$-selected, often overexploited, fishes (Castro 1993, Bonfil 1997, Camhi 1998, Simpfendorfer \& Heupel 2004). Much of this research has occurred in nearshore areas of continental shelves, especially large estuaries, which are hypothesized to be nursery areas for these species (Castro 1993, Simpfendorfer \& Milward 1993, Camhi 1998, Merson \& Pratt 2001, Heupel \& Hueter 2002). Within these areas, larger, older individuals often occupy deeper areas than those utilized by smaller, younger individuals; ostensibly this is a means for small sharks to avoid being preyed upon by larger conspecifics (Springer 1967, Castro 1993, Morrissey \& Gruber 1993, Heupel \& Hueter 2002). Although our understanding of juvenile habitat use is improving for sharks which breed on the continental shelves and in large estuaries of the western Atlantic, relatively little is known about age-specific habitat partitioning in reef-associated sharks in this region.

In this paper we report the results of a $5 \mathrm{yr}$ spring and summer survey of the sharks and batoids of Glover's Reef, conducted using standard longlining and various non-standard collection methodologies. The study objectives were to (1) assess the elasmobranch species diversity from April to July; (2) determine whether early life-stages (neonates, small juveniles) of species inhabiting the atoll utilize this offshore reef system; (3) determine species- and age-specific patterns of abundance in different reef macrohabitats around the atoll based on results of standardized longline fishing; and (4) describe the demographic population structure and some life-history characteristics of common species. In addition to the survey results, we report findings at 2 fish markets in adjacent coastal locations, which were used to gather preliminary information on coastal shark diversity and demography in Belize to complement data obtained from the offshore site.

\section{MATERIALS AND METHODS}

Site description. Glover's Reef atoll $\left(16^{\circ} 44^{\prime} \mathrm{N}\right.$, $87^{\circ} 48^{\prime} \mathrm{W}$ ) lies approximately $25 \mathrm{~km}$ to the east of the Mesoamerican Barrier Reef and $45 \mathrm{~km}$ east of the Belizean mainland (Fig. 1). The Glover's Reef Marine Reserve (GRMR) comprises an interior no-take 'conservation zone' (7226 ha [Gibson et al. 2004]; present Fig. 1), surrounded by a regulated 'general use zone', which covers the entire atoll out to the $180 \mathrm{~m}$ depth contour (32 834 ha [Gibson et al. 2004]; present Fig. 1). To the north and west of the atoll, depths range from 300 to $400 \mathrm{~m}$, while depths to the east (windward) side rapidly drop to over $1000 \mathrm{~m}$. The edge of the insular slope at Glover's Reef ranges from 15 to $45 \mathrm{~m}$ depth and the fore-reef is less than $500 \mathrm{~m}$ wide in most areas. The windward (eastern) ocean reefs, composed largely of low-relief spur and groove formations (mainly Montastrea spp., Diploria spp.), are better developed and wider than the leeward (western) ocean reefs. The atoll itself is approximately $30 \mathrm{~km}$ long and a maximum of approximately $10 \mathrm{~km}$ wide. The reef crest on the west side of the atoll is submerged (ca. 1.5 to $2 \mathrm{~m}$ depth), while the reef crest on the eastern side of the atoll is exposed and is broken by 5 cuts which connect the ocean reef and lagoon habitats. The lagoon is basin shaped and is up to $18 \mathrm{~m}$ deep in some areas, with approximately 850 patch reefs (10 to $300 \mathrm{~m}+$ wide) scattered throughout the interior, which are composed largely of massive corals (Montastrea spp., Diploria spp., Siderasteria spp.). There are 6 cayes along the eastern edge of the lagoon, some of which are at least partially fringed with mangroves and surrounded on the lagoon side by seagrass flats in shallow water ( $<1.5 \mathrm{~m}$ depth). Average annual rainfall is $175 \mathrm{~cm}$, with the main rainy season from June to October, and normal marine salinities occurring in the lagoon throughout the year. Water temperature usually ranges from 27 to $32^{\circ} \mathrm{C}$ (summarized from Gibson 2003).

Longline sampling. Commercial grade longline gear was used under a research permit from the Belize Department of Fisheries to capture elasmobranchs during 6 sampling expeditions conducted between July 2000 and May 2004. Five 12 d (July in 2000, early May/June in 2001, 2002, 2003 and 2004) and one 5 d (April 2003) expeditions were completed. The longline gear consisted of a $5.6 \mathrm{~mm}$ tarred, braided, nylon main- 


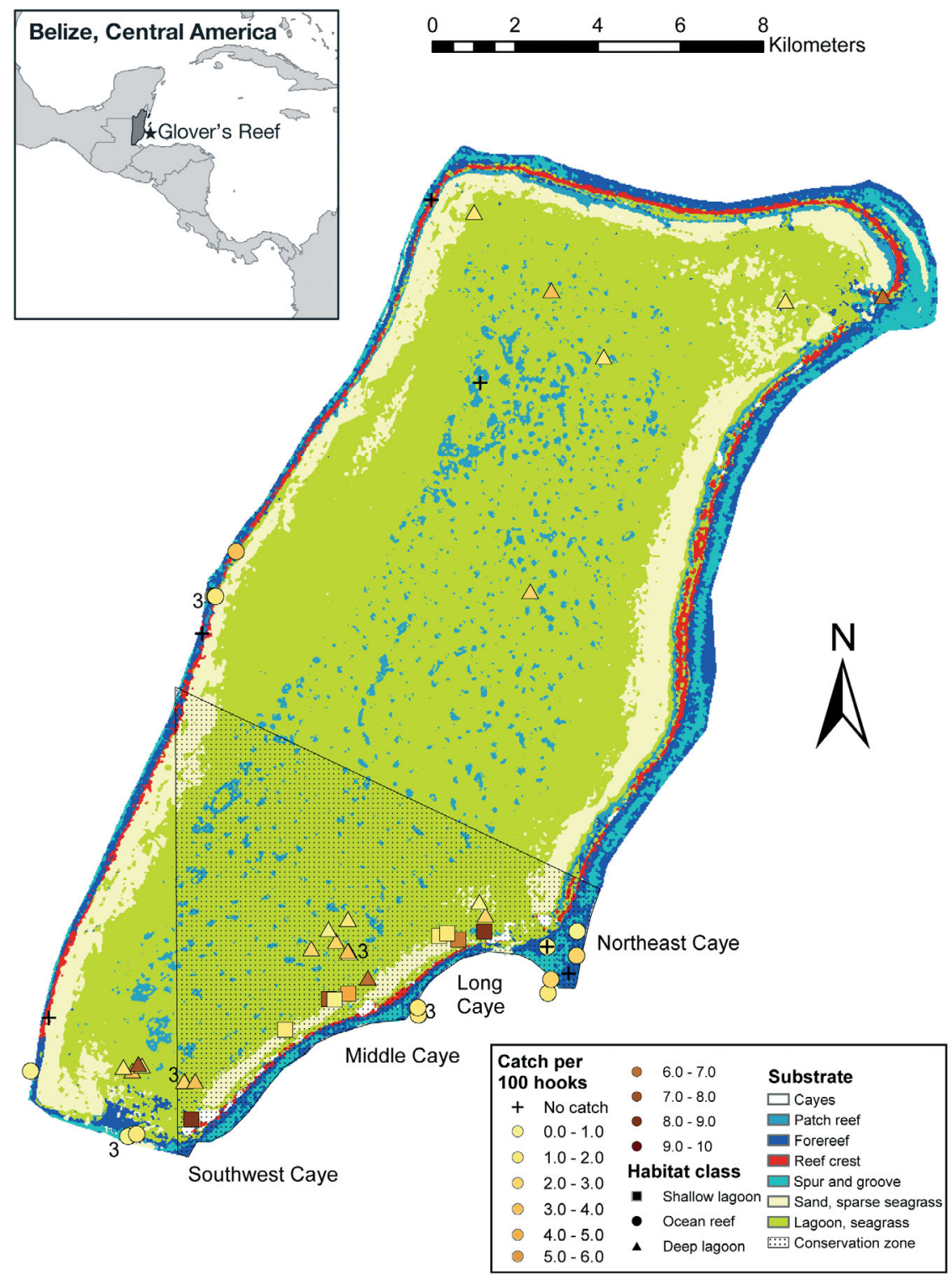

Fig. 1. Glover's Reef atoll, Belize, showing longline locations plotted by total elasmobranch catch rate and habitat type. Numbers next to habitat class locations indicate multiple longline sets

line that was anchored to the substrate at both ends. Baited gangions were placed at $20 \mathrm{~m}$ intervals along the mainline, and floats were attached at regular intervals to buoy the line. Each gangion was $3.5 \mathrm{~m}$ in length and was composed of a $2.5 \mathrm{~m}$ section of $2 \mathrm{~mm}$ monofilament connected to a $1.0 \mathrm{~m}$ section of $1.6 \mathrm{~mm}$ stainless steel cable, terminating in a 16/0 Mustad circle hook. Each hook was baited with similar-sized pieces of resident fish species captured locally (primarily from the families Lutjanidae, Haemulidae, Sphyraenidae, Carangidae). The only change in the sampling gear made during the course of the study was in hook size. For the pilot study conducted in 2000, 14/0 circle hooks were used, while in later years we used 16/0 circle hooks in order to reduce the incidental catch of large teleosts.

During the course of the study, 2 types of longline sets were made to capture specimens. Standard lines were used to provide quantitative estimates of elasmobranch abundance and to describe their distribution at Glover's Reef. These lines were deployed for $3 \mathrm{~h}$ at fixed locations each year, with the number of hooks deployed ranging from 15 to 70 (> $85 \%$ of standard lines had from 50 to 70 hooks). The variation in hook number between some locations for standard sites could not be avoided because of the difficulty of setting lines around the numerous patch reefs inside Glover's Reef. At each standard site, the same number of hooks were set across the multiple years of the study. For quantitative data analysis, we used catch per unit effort (CPUE, sharks 100 hooks $^{-1} \mathrm{~h}^{-1}$ ) as the statistical sampling unit. Non-standard lines included the sets made during July 2000 with smaller circle hooks, and a few sets made in later years when sudden thunderstorms caused us to delay checking the line until after $3 \mathrm{~h}$. We did not use CPUE data from non-standard longline sets in the statistical analysis, but the biological data from the specimens caught were used for investigations of the local demography of each species.

Elasmobranch handling and data collection. All captured elasmobranchs were secured to the side of the $7 \mathrm{~m}$ fishing vessel with the gangion tied to the bow and a rope-noose looped around the tail and attached to the stern. This allowed data collection while keeping the shark in the water. The total length (TL) of all sharks was measured on a straight line from the tip of the rostrum to the tip of the upper caudal lobe, and sex was determined by examination of the pelvic region for the presence of claspers in the male. Inner clasper length (CL) was measured following the standards used by Castro (2000). Small sharks were examined for an umbilical opening, to determine whether they were neonates. Live sharks (ca. $94 \%$ of the catch) were then tagged using individually numbered nylon-tipped dart tags (Hallprint). Each 
hook was completely removed using a pair of bolt cutters before the shark was released. Total handling time typically varied from about 5 to $8 \mathrm{~min}$. Dead sharks were retained for later dissection, collection of vertebral samples, stomach content analysis and measurements of embryos in gravid females. Teleost by-catch was released alive when caught within the no-take zone of GRMR, or otherwise retained for bait.

Identification of Galápagos shark Carcharhinus galapagensis. On May 25, 2001, a 154 cm TL female carcharhinid shark was captured on a standard longline running along the edge of the reef slope at the southern entrance of Glover's Reef. Based on its external morphology, it was determined to be either a dusky shark Carcharhinus obscurus, or a Galápagos shark C. galapagensis. Neither of these species had previously been recorded for Belizean waters (Compagno 1984). The only known method of distinguishing these species morphologically with confidence is through vertebral counts (Compagno 1984), which would require sacrificing the shark. The individual in question was in good condition and, as a requirement of the project research permit, was tagged and released alive, with a tissue sample taken for later DNA analysis. The shark was subsequently identified as $C$. galapagensis by comparing its nuclear ribosomal internal transcribed spacer 2 (ITS2) locus sequence (a region of DNA commonly used for species discrimination in sharks; Pank et al. 2001, Shivji et al. 2002, Chapman et al. 2003), with this sequence from voucher C. obscurus and C. galapagensis specimens (full description of methodology available from author M. S. Shivji upon request).

Collection of elasmobranchs by non-standard methods. To supplement longline sampling, several non-standard sampling gears - monofilament gill-nets (180 m, 4 inch [10.16 cm] stretch mesh), seines and hand-held dip-nets - were used to collect young sharks and smaller batoids on the shallow $(<1.5 \mathrm{~m})$ reef flats adjacent to the mangrove-fringed shorelines of 3 small islands (Long, Middle and Southwest Cayes) on the SE edge of the lagoon. The sampling regime for nonstandard sets involved first visually spotting sharks and rays over the shallow seagrass flats and then deploying either a seine, gill-net or dip-net around them. The same data (measurements, sex, presence of an umbilical opening) were collected for individuals caught in this manner as for longline-captured sharks.

On April 22, 2003, 6 drumlines were set along the west side of Glover's Reef at the edge of the ocean reef (where the bottom drops off from 30 to $>400 \mathrm{~m}$ ) in an attempt to catch large pelagic sharks. Each drumline consisted of a standard gangion attached to a very large float, which was then attached to the substrate by a length of the standard longline (i.e. tarred, braided nylon) ending in a grapnel anchor and cement block. These were deployed from 09:00 to 13:00 h, baited with large pieces of great barracuda Sphyraena barracuda. The handling and data collection for 1 shark captured on these drumlines were identical to those for sharks caught on standard longlines.

Opportunistic fish market surveys. We made 7 visits to fish markets in Dangriga (6) and Belize City (1) on the Belizean coast adjacent to Glover's Reef atoll during April and May, 2001 through 2003, with the goal of finding and identifying elasmobranchs exploited by local fisheries. The approximate life-stage was determined by size and examination of the umbilicus as described in an earlier subsection. Interviews were conducted with fishermen to determine the approximate locations at which specimens had been caught.

Statistical analyses. Standard longline set locations were each categorized into 1 of 3 classes in order to compare overall abundance, species composition and patterns of species-specific abundance in different macrohabitats around Glover's Reef atoll (Fig. 1). These classifications were based on benthic habitat data for Glover's Reef provided by the Belize Coastal Zone Management Authority and Institute (CZMAI), coupled with depth measurements made at varying intervals along the standard longlines. The longline CPUE data were mapped onto the habitat classification data layer (Fig. 1) using ArcMap 9.0 GIS software (ESRI). We defined 'ocean reef' lines as those set along the reef-slope and fore-reef fringing Glover's Reef over a coral reef substrate in 6 to $30 \mathrm{~m}$ of water; 'deep lagoon' lines were those set inside the atoll in 6 to $18 \mathrm{~m}$ of water with mixed seagrass, soft bottom and patch reef substrates; 'shallow lagoon' lines were those set in the lagoon on the reef flats in water $<3 \mathrm{~m}$ deep.

To test whether year or habitat had significant effects on elasmobranch CPUE (all species combined and for common species individually), MANOVA and ANOVA tests were performed, using SPSS Version 13.0 for Windows. In all cases, CPUE data were log-transformed $[\ln (\mathrm{CPUE}+1)]$ to normalize the data. For the MANOVA tests, equality of the covariance matrices was tested with Box's test, and the significance of the year effect, habitat effect, and the interaction between year and habitat were tested with Wilks' lambda (Huberty \& Petoskey 2000). Post-hoc comparisons were conducted using both Bonferroni and Tukey's HSD tests.

The size distributions of Ginglymostoma cirratum and Carcharhinus perezi were compared among the 3 habitats. Sex ratios observed for these 2 species were also tested for departure from equality using chisquare. To characterize the size at which males begin to mature, a scatterplot comparing CL and TL was inspected to infer the length range in which there is a 
rapid elongation of the claspers, which is associated with the onset of sexual maturity in elasmobranchs (Castro 2000).

\section{RESULTS}

During the 6 expeditions conducted from July 2000 through May 2004, 63 standard and 15 non-standard longline sets were made in and around Glover's Reef atoll (Fig. 1). The total elasmobranch longline catch was 318 individuals, comprising 6 species of sharks and 1 batoid (southern stingray Dasyatis americana). Of the elasmobranchs captured, $94 \%$ were tagged and released alive. Overall, nurse sharks Ginglymostoma cirratum had the highest relative abundance $(57.8 \%$ of catch), followed by Caribbean reef sharks Carcharhinus perezi $(32.3 \%)$, southern stingrays $D$. americana (5.6\%), Caribbean sharpnose sharks Rhizoprionodon porosus $(1.8 \%)$, lemon sharks Negaprion brevirostris $(1.2 \%)$, silky sharks C. falciformis $(0.06 \%)$ and a Galàpagos shark C. galapagensis $(0.03 \%)$.

We made 27 standard sets in the deep lagoon, 26 in the ocean reef and 10 in the shallow lagoon (Table 1), with a total of 3428 individual hooks. In the standard

Table 1. Number of standard longline sets at Glover's Reef Marine Reserve, Belize, by habitat and year

\begin{tabular}{|ccccc|}
\hline Year & Deep lagoon & Ocean reef & Shallow lagoon & Total \\
\hline 2001 & 9 & 5 & 3 & 17 \\
2002 & 7 & 4 & 2 & 13 \\
2003 & 5 & 7 & 2 & 14 \\
2004 & 6 & 10 & 3 & 19 \\
Total & 27 & 26 & 10 & 63 \\
\hline
\end{tabular}

Table 2. Analysis of total elasmobranch catch per unit effort (CPUE) in standard longline sets. (a) ANOVA of log-transformed CPUE; (b) Bonferroni pairwise comparisons among habitats. DLAG: deep lagoon; OREEF: ocean reef; SLAG: shallow lagoon

\begin{tabular}{|lrrrrc|}
\hline (a) & & & & & \\
Source & Type III SS & df & MS & $F$ & $\mathrm{p}$ \\
\hline Model & 90.59 & 12 & 7.55 & 23.07 & 0.000 \\
Year & 0.98 & 3 & 0.33 & 1.00 & 0.402 \\
Habitat & 4.77 & 2 & 2.39 & 7.29 & 0.002 \\
Year $\times$ Habitat & 1.33 & 6 & 0.22 & 0.68 & 0.669 \\
Error & 16.69 & 51 & 0.33 & & \\
Total & 107.28 & 63 & & & \\
(b) & & & & & \\
Habitat (I) & Habitat (J) & Mean difference (I-J) & SE & p \\
\hline DLAG & OREEF & 0.44 & 0.15 & 0.019 \\
DLAG & SLAG & -0.23 & 0.21 & 0.833 \\
OREEF & SLAG & -0.67 & 0.21 & 0.007 \\
\hline
\end{tabular}

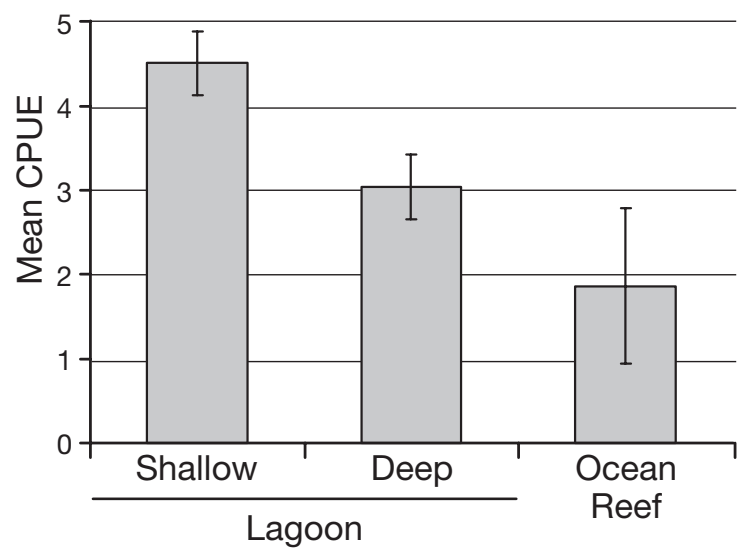

Fig. 2. Mean $( \pm \mathrm{SE})$ catch per unit effort (CPUE) for each macrohabitat type (all elasmobranch species combined)

longline sets, total CPUE varied with habitat, but not with year, and the year $\times$ habitat interaction was not significant (Table 2a). Total CPUE (Fig. 2, Table 2b) was higher in both the deep lagoon and the shallow lagoon than in the ocean reef. Of the 7 species caught in the standard longline sets, only Ginglymostoma cirratum, Carcharhinus perezi, and Dasyatis americana were caught in more than 1 habitat type and during all years of the study (Table 3, Fig. 3). The multivariate CPUE of these 3 species varied with habitat but not year, and again there was no significant year $\times$ habitat interaction (Table 4a). The CPUE of G. cirratum was higher in both the shallow lagoon and deep lagoon

Table 3. Ginglymostoma cirratum (Gci), Carcharhinus perezi (Cpe), Negaprion brevirostris (Nbr), C. falciformis (Cfa), Rhizoprionodon porosus (Rpo), C. galapagensis (Cga), Dasyatis americana (Dam). Number of sharks caught as a function of habitat type and year in standard longline sets. DLAG: deep lagoon; OREEF: ocean reef; SLAG: shallow lagoon

\begin{tabular}{|lrrrccccc|}
\hline Habitat & Gci & Cpe & Nbr & Cfa & Rpo & Cga & Dam & Total \\
\hline 2001 & & & & & & & & \\
DLAG & 23 & 7 & & & 2 & & 1 & 33 \\
OREEF & 1 & 13 & & 1 & & 1 & & 16 \\
SLAG & 18 & 1 & & & & & 2 & 21 \\
2002 & & & & & & & & \\
DLAG & 23 & 15 & & & 1 & & 3 & 42 \\
OREEF & 5 & 6 & & & & & 1 & 11 \\
SLAG & 11 & 0 & 1 & & & & & \\
2003 & & & & & & & 1 & 28 \\
DLAG & 22 & 5 & & & & & & 28 \\
OREEF & 2 & 25 & & & 1 & & 1 & 8 \\
SLAG & 6 & 0 & 1 & & & & & \\
2004 & & & & & & & 2 & 23 \\
DLAG & 16 & 5 & & & & & & 19 \\
OREEF & 7 & 12 & & & & & 1 & 10 \\
SLAG & 8 & 1 & & & & 1 & 12 & 252 \\
Total & 142 & 90 & 2 & 1 & 4 & 1 & \\
\hline
\end{tabular}




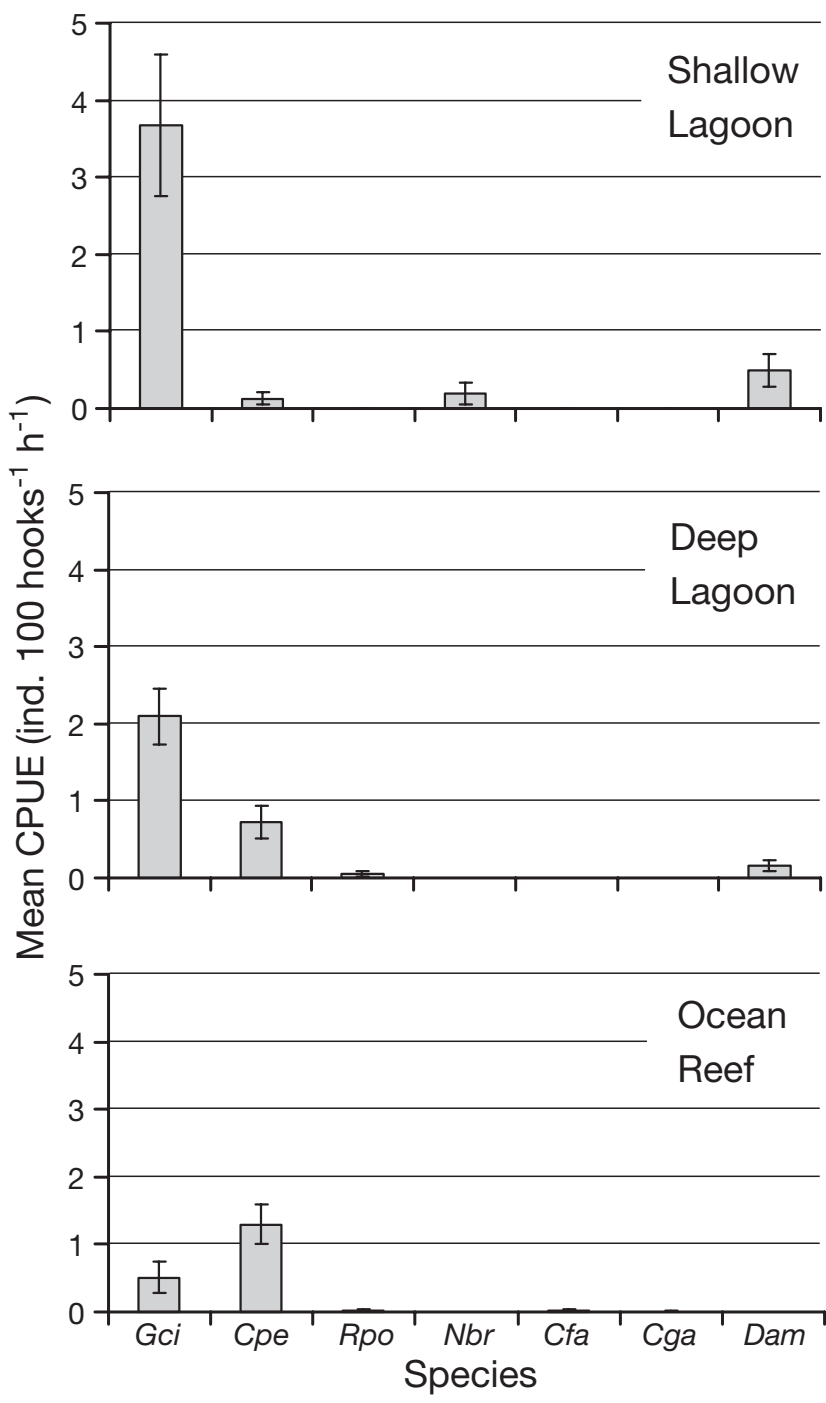

Fig. 3. Ginglymostoma cirratum (Gci), Carcharhinus perezi (Cpe), Rhizoprionodon porosus (Rpo), Negaprion brevirostris $(\mathrm{Nbr})$, C. falciformis (Cfa), C. galapagensis (Cga) and Dasyatis americana $(D a m)$. Mean $( \pm \mathrm{SE})$ catch per unit effort (CPUE) for each elasmobranch species on all standard longline sets within the 3 reef types

than in the ocean reef; $C$. perezi CPUE was higher in the ocean reef than in the shallow lagoon; and $D$. americana CPUE was higher in the shallow lagoon than the ocean reef (Table 4b, Fig. 3).

Length-frequency histograms for Ginglymostoma cirratum and Carcharhinus perezi (Figs. 4 \& 5, respectively) from all longline sets show that a wide range of life-stages of these species, from juveniles to adults, are present at Glover's Reef in spring/summer. For G. cirratum, juveniles were caught in all 3 habitats, but large adults of both sexes were only commonly caught in the deep lagoon (Fig. 4). The median and modal lengths of both male and female nurse sharks increased between the shallow lagoon (median female
Table 4. Ginglymostoma cirratum (Gci), Carcharhinus perezi (Gpe) and Dasyatis americana (Dam). Analysis of the multivariate response variable of the log-transformed CPUE. (a) MANOVA using the Wilks' lambda test statistic. The covariances matrices were not significantly different between groups (Box's test, $\mathrm{p}=0.22$ ); (b) Bonferroni post-hoc multiple comparisons of log-transformed CPUE of each species between habitats. Tukey HSD results were similar and are not reported. DLAG: deep lagoon; OREEF: ocean reef; SLAG: shallow lagoon

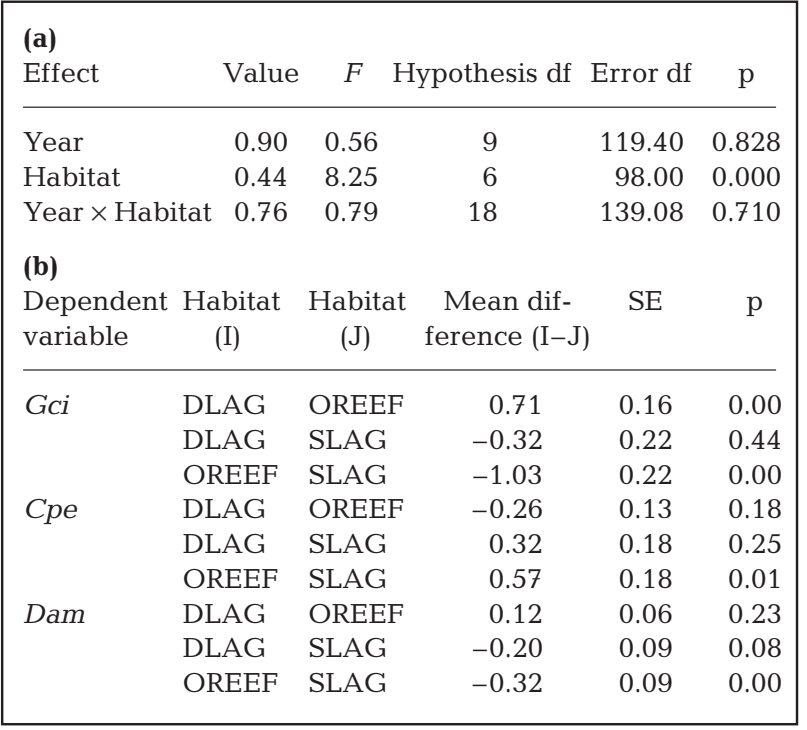

TL $156 \mathrm{~cm}$, mode $156 \mathrm{~cm}$; median male TL $150.5 \mathrm{~cm}$, mode $152 \mathrm{~cm}$ ) and deep lagoon (median female TL $178.5 \mathrm{~cm}$, mode $170 \mathrm{~cm}$; median male TL $178.5 \mathrm{~cm}$, mode $169 \mathrm{~cm}$ ). No G. cirratum smaller than $100 \mathrm{~cm}$ TL were caught on longlines, which precludes an assessment of the location of neonates using this method (but see non-standard sampling described below). Like $G$. cirratum, juvenile $C$. perezi occurred in all 3 habitats, but only 2 small (103 cm TL) sharks were caught in the shallow lagoon. Small juvenile C. perezi were common in both the deep lagoon and the ocean reef, but larger juveniles (>140 cm TL) were not caught and adults were uncommon in the deep lagoon (Fig. 5). The median TL of both male and female $C$. perezi increased from the deep lagoon (median female TL $110 \mathrm{~cm}$; median male TL $112 \mathrm{~cm}$ ) to the ocean reef (median female TL $136 \mathrm{~cm}$; median male TL $117 \mathrm{~cm}$ ). One $81 \mathrm{~cm}$ TL C. perezi captured on the ocean reef in July 2000 was judged to be a very recently born neonate, based on the presence of a large, open umbilicus.

The relationship between male TL and CL suggests that male Carcharhinus perezi at Glover's Reef are maturing from 150 to $170 \mathrm{~cm}$ TL and male Ginglymotsoma cirratum from 185 to $200 \mathrm{~cm}$ TL (Fig. 6) at this location. The observed sex ratio for $G$. cirratum was 77 males:78 females and 51 males:52 females for $C$. 


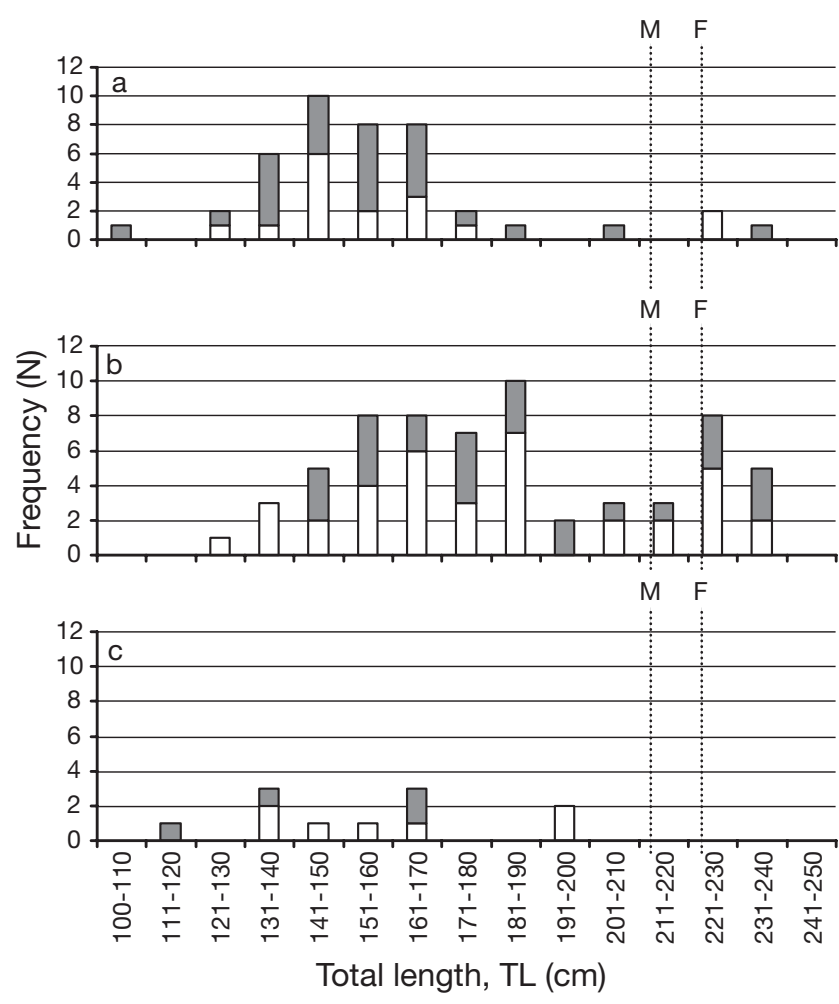

Fig. 4. Ginglymostoma cirratum. Length-frequency histogram for males (open bars) and females (black bars) captured at Glover's Reef in (a) shallow lagoon, (b) deep lagoon and (c) ocean reef. Vertical dotted lines show approximate total lengths at maturity (from Castro 2000) for males (M) and females $(F)$

perezi; neither ratio differed significantly from 1:1. We recorded 4 definite captures of gravid female sharks at Glover's Reef during standard longline sets. Of these, 1 was a $258 \mathrm{~cm}$ TL Negaprion brevirostris captured on a shallow lagoon line $(<1.5 \mathrm{~m}$ depth) within $1 \mathrm{~km}$ of Middle Caye, which birthed 1 pup during tagging. The other 3 sharks were gravid Rhizoprionodon porosus captured on deep lagoon lines, 2 of which died prior to line recovery and were dissected to determine the number of embryos and their sizes: a $98 \mathrm{~cm}$ TL female contained 4 embryos ( 2 males and 2 females, 31 to $34 \mathrm{~cm} \mathrm{TL}$ ), while an $84 \mathrm{~cm}$ TL female contained 2 embryos (both males, 31 and $32 \mathrm{~cm} \mathrm{TL}$ ).

Non-standard sampling of shallow reef flat areas adjacent to the mangrove-fringed cayes resulted in the capture of 3 Ginglymostoma cirratum, 22 Negaprion brevirostris, 34 Dasyatis americana, 2 spotted eagle rays Aetobatus narinari and 1 yellow stingray Urolophus jamaicensis. Of the $N$. brevirostris caught, 9 $(40.9 \%)$ were neonates based on the condition of their umbilical opening and their TL (61.2 to $66.2 \mathrm{~cm})$. Of the G. cirratum, 2 were also judged to be neonates, based on their small size (ca. $30 \mathrm{~cm} \mathrm{TL}$ ) and spotted markings typical of neonates of this species (Castro 2000). One D. americana measured $28 \mathrm{~cm}$ across the disc, close to

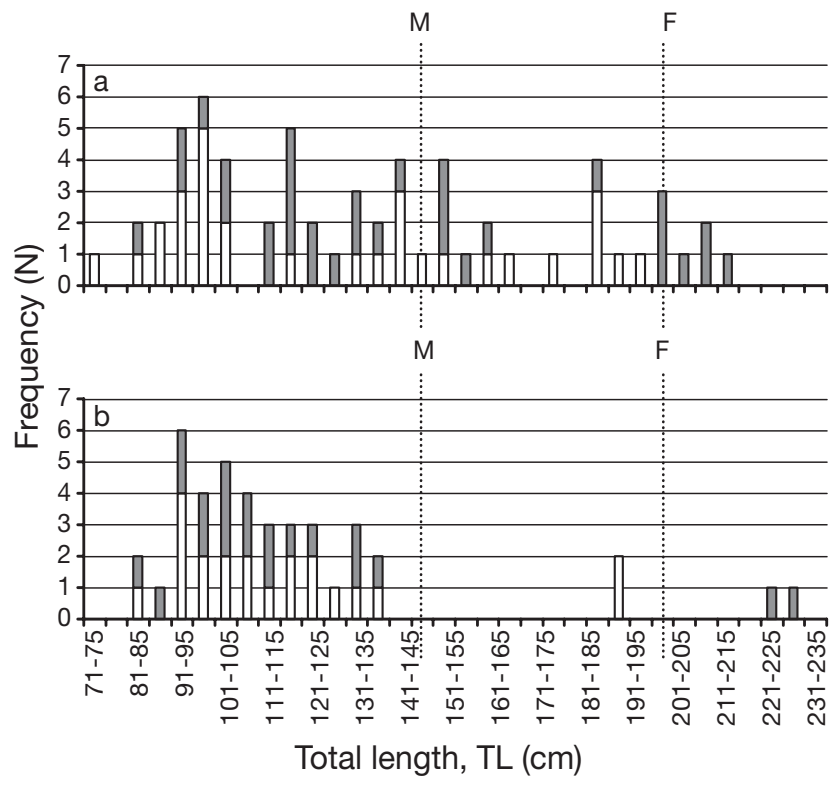

Fig. 5. Carcharhinus perezi. Length-frequency histograms for males (open bars) and females (black bars) captured at Glover's Reef in ocean reef and deep lagoon. Vertical dotted lines show approximate total lengths at maturity (from Compagno 1984) for males (M) and females (F). Only 2 sharks were caught in the shallow lagoon (not shown)

the size at birth given by Henningsen (2000). We recorded 3 additional elasmobranch species at Glover's Reef using non-standard sampling methods. We observed 2 tiger sharks Galeocerdo cuvier; 1 was ca. $200 \mathrm{~cm}$ TL and was accidentally struck and killed by a boat inside the lagoon in early May 2001 (specimen retained by Belize Department of Fisheries officers);

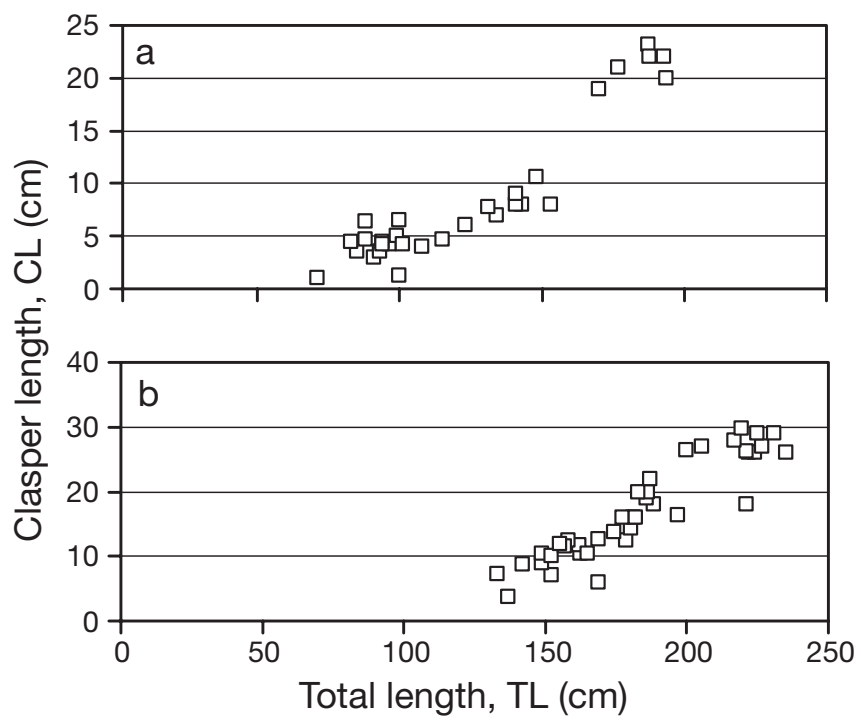

Fig. 6. (a) Carcharhinus perezi and (b) Ginglymostoma cirratum. Relationship between clasper length (CL) and total length (TL) in males showing that the onset of maturity (rapid elongation of claspers) occurs in these species at 150 to $170 \mathrm{~cm}$ and 185 to $200 \mathrm{~cm} \mathrm{TL}$, respectively 
the second specimen, an immature $211 \mathrm{~cm}$ TL female, was captured on a single-hook drumline set on April 22,2003 , on the ocean reef on the western edge of Glover's Reef. On April 24, 2003, a ca. 2.5 m TL great hammerhead shark Sphyrna mokarran was hooked on light tackle while bait fishing inside the lagoon and brought alongside the boat long enough for confirmation of its species identity (Compagno 1984). Finally, a whale shark Rhincodon typus was observed on April 25, 2003, at the surface on the ocean reef near the southern entrance to the lagoon.

Shark collections at the 2 coastal fish markets yielded a total of 57 intact specimens, consisting of 30 blacktips Carcharhinus limbatus (18 neonates, 12 juveniles <90 cm TL), 2 Negaprion brevirostris (1 neonate, 1 juvenile $156 \mathrm{~cm}$ TL), 22 bonnetheads Sphyrna tiburo (all juveniles <60 cm TL), 1 scalloped hammerhead $S$. lewini (neonate), 1 great hammerhead S. mokkaran (juvenile $<90 \mathrm{~cm} \mathrm{TL}$ ), and 1 Rhizoprionodon porosus (neonate). Discussions with fishermen indicated these were all captured inshore on the coastal side of the barrier reef between Dangriga and Belize City.

\section{DISCUSSION}

Although we detected no significant changes in overall elasmobranch abundance from 2001 to 2004, the spring-summer elasmobranch assemblage of Glover's Reef is clearly structured by habitat (depth and reef type). Total elasmobranch abundance was significantly higher in the shallow lagoon and deep lagoon than the ocean reef, and both these lagoon habitats were dominated by Ginglymostoma cirratum, which appears to be the most abundant shark at Glover's Reef. The batoid Dasyatis americana was also common in both deep and shallow parts of the lagoon, while catches of Negaprion brevirostris and Rhizoprionodon porosus were restricted to the shallow and deep parts of the lagoon, respectively. Carcharhinus perezi were frequently caught in the deep lagoon but only rarely in the shallow lagoon, and were the most abundant species on the ocean reef. Other species caught in the ocean reef habitat included those commonly found in the lagoon ( $G$. cirratum, $R$. porosus) and rare captures of pelagic sharks (C. falciformis, C. galapagensis). The overall elasmobranch diversity of Glover's Reef in the spring-summer period of 2000 to 2004, based on all collection methods and field observations, was 12 species.

Neonates and small juveniles of at least 3 sharks (Ginglymostoma cirratum, Carcharhinus perezi and Negaprion brevirostris) and 1 batoid (Dasyatis americana) utilize Glover's Reef, indicating that parturition occurs at this location. This was confirmed for $N$. brevirostris by the capture of a near-term gravid female. A 4th shark species, Rhizoprionodon porosus, may also use Glover's Reef for parturition, as suggested by the presence of gravid females with large embryos in May to June. However, as noted by Castro (1993), female sharks can migrate long distances immediately prior to parturition, so the role of Glover's Reef in the life cycle of this species remains unclear. The absence of neonatal or juvenile $R$. porosus in the longline catch may well be the result of gear selectivity, as these very small sharks would not be captured on the large hooks used in this study.

The observed sex ratios of Ginglymostoma cirratum and Carcharhinus perezi sampled using longlines at Glover's Reef indicated that nearly equal numbers of males and females are present from May to July. The CL rapidly increases when males are 150 to $170 \mathrm{~cm}$ TL and 185 to $200 \mathrm{~cm}$ TL in G. cirratum and C. perezi, respectively. These estimates for the onset of sexual maturity are similar to size-at-maturity estimates given by Compagno (1984) and Castro (2000). The presence of mature individuals of both sexes suggests that Glover's Reef could also be a mating ground for these species, but additional sampling and examination of specimens would be required to confirm this possibility. Chapman et al. (2005) have found that adult male and female G. cirratum remain around Glover's Reef from May to October, which encompasses the known mating season for this species in Florida and the Bahamas (Castro 2000).

Evidence for age-specific habitat partitioning was found for Ginglymostoma cirratum, Negaprion brevirostris and Carcharhinus perezi. Larger G. cirratum were more commonly captured on standard longline sets in the deep than in the shallow parts of the lagoon (see Fig. 4) and 2 neonates were captured with nonstandard methods within seagrass beds in shallow, nearshore waters. This suggests that juveniles of this species in the lagoon may initially inhabit in the shallow waters close to shore and move into deeper water as they grow. Similarly, in $N$. brevirostris, neonates and juveniles were only captured over very shallow (<1.5 m depth), nearshore seagrass beds, often adjacent to mangroves, while larger juveniles (>120 cm TL) were caught only on lines set in the shallow lagoon further from the shore. Adult $N$. brevirostris were absent from all macrohabitats sampled at Glover's Reef, with the exception of 1 gravid female caught in the shallow lagoon that had presumably migrated into the area for parturition. Collectively, these observations are consistent with the use of discrete, shallow, nearshore nurseries by this species, with the adults only seasonally visiting these nursery areas for purposes of parturition or mating (Compagno 1984, Gruber et al. 1988, Castro 1993, Feldheim et al. 2001). In contrast, adult C. perezi were common at Glover's Reef, and were captured 
mainly on the ocean reef. Small juveniles were distributed in both the deep lagoon and ocean reef, while larger juveniles (>140 cm TL) were absent from deep lagoon catches. These findings suggest that as $C$. perezi grow, their use of the deep lagoon diminishes. Small juvenile C. perezi were only rarely captured in the shallow lagoon $(<2 \mathrm{~m}$ depth), indicating that this species avoids shallow, seagrass flats throughout its life, in marked contrast to G. cirratum and N. brevirostris. A parallel automated telemetry tracking study is beginning to corroborate these observations for adult and large juvenile $C$. perezi (Chapman et al. 2005). Although 4 C. perezi fitted with transmitters ranged widely around the atoll from May to October 2004 , only 1 of these was ever detected on receivers placed in the shallow lagoon, and then for only a few minutes on 1 day (Chapman et al. 2005). In addition, while the 2 juvenile sharks moved between the ocean reef and deep lagoon, the 2 adults were only detected on ocean reef receivers (Chapman et al. 2005).

Prior to this study, species- and age-specific habitat use patterns of sharks on coral reefs had not been quantitatively described in the Caribbean, although interspecific partitioning of reef habitats by depth and substrate type has been qualitatively described among carcharhinid sharks on coral reefs in the Pacific (Johnson 1978, McKibben \& Nelson 1986, Tricas 1987, Wetherbee et al. 1997). Observations at these Pacific coral reefs, many of which are atolls, indicate that blacktip reef sharks Carcharhinus melanopterus are most common on the shallow reef flats of lagoons, grey reef sharks C. amblyrhynchos are most common in deeper parts of the lagoon, and C. amblyrhynchos, $C$. galapagensis and silvertip sharks $C$. albimarginatus dominate the ocean reef assemblage. Among Glover's Reef carcharhinids, it appears that juvenile Negaprion brevirostris parallel the depth and substrate distribution of C. melanopterus, small juvenile C. perezi parallel $C$. amblyrhynchos in their use of the deeper part of the lagoon, and juvenile (all sizes) and adult $C$. perezi, C. falciformis and C. galapagensis occupy the ocean reef habitat range observed for $C$. albimarginatus, C. galapagensis and C. amblyrhynchos in the Pacific. The structuring of reef shark assemblages in both the Caribbean and Pacific by depth and substrate type implies that reserves should be designed to include diverse habitats in order to adequately conserve shark assemblages.

This survey provides the first record of a Galápagos shark Carcharhinus galapagensis on the Mesoamerican Barrier Reef, and is also only the second verified capture of this species in the Caribbean Sea, the other being the capture of 1 individual in the US Virgin Islands in 1963 (Compagno 1984). The global distribution of C. galapagensis remains difficult to determine, in part due to confusion with similar congeners, particularly C. obscurus (Compagno 1984, Taniuchi et al. 1985, Brum \& Azevedo 1995, Wetherbee et al. 1996). Since C. galapagensis tend to be more common around subtropical and tropical oceanic islands whereas $C$. obscurus is more abundant in continental areas (Compagno 1984), the paucity of records of C. galapagensis from offshore coral reefs in the Caribbean Sea is surprising. C. galapagensis may be relatively rare in the Caribbean, perhaps due to competitive exclusion by the far more common insular species C. perezi. However, it is possible that identification difficulties and the limited faunal surveys of sharks in the region have obscured the presence of $C$. galapagensis in the Caribbean.

Opportunistic coastal fish market surveys documented the presence of neonates and small juveniles of 6 shark species caught inside the barrier reef, specifically, Carcharhinus limbatus, Sphyrna tiburo, S. lewini, S. mokarran, Negaprion brevirostris and Rhizoprionodon porosus. These results show that inshore locations in Belize are used by early life-stages of a diversity of shark species and may harbor coastal nursery areas similar to those described in other locations in the western Atlantic.

The results of this study indicate that inshore and offshore locations are utilized by early life-stages of at least 9 elasmobranch species in Belize and that GRMR is utilized by at least 12 elasmobranch species during the spring and summer months. The presence of neonate and small juvenile Ginglymostoma cirratum, Carcharhinus perezi, Negaprion brevirostris, and Dasyatis americana indicates that the atoll is used for purposes of breeding by these species. The elasmobranch assemblage of Glover's Reef exhibits patterns of interspecific habitat partitioning by reef type and depth, reminiscent of habitat partitioning of reef-associated sharks in the Pacific. Overall, this study implies that some of the other unexplored oceanic atolls and inshore areas along the Mesoamerican Barrier Reef and Belizean coast may also support breeding areas for sharks, and could also harbor populations of difficultto-identify elasmobranch species, such as C. galapagensis. Because commercial exploitation of elasmobranchs for food (fins, meat) and ecotourism (primarily dive-tourism involving G. cirratum, C. perezi, Rhincodon typus, and D. americana) is increasing in Belize (Heyman et al. 2001, Carwardine \& Watterson 2002, Gibson et al. 2004), we suggest that more intensive and informed conservation and fisheries management may be required for elasmobranchs in this region. Therefore, relatively unexplored ecosystems such as the oceanic atolls, the barrier reef and parts of the coast warrant further surveying and study, to ensure that the full diversity of Belizean elasmobranchs is documented 
and considered for inclusion in a comprehensive conservation and fisheries management plan for these highly vulnerable apex predators.

Acknowledgements. This project was funded by the Pew Charitable Trusts through a Pew Fellowship grant to E.K.P., the Wildlife Conservation Society, the Oak Foundation, a National Science Foundation Fellowship (to D.D.C.) and the Seastar Foundation. We thank the Belize Coastal Zone Management Authority and Institute (CZMAI) for providing the habitat data under a memorandum of understanding with the Wildlife Conservation Society, and the Belize Department of Fisheries for providing research permits. Thanks to D. Abercrombie, D. Grubbs, M. Drake, V. Richards, S. Harrison, M. Henning, K. Feldheim, T. Calver, B. Henneman, S. Pikitch, G. Myers, R. Enriquez, E. Lauck, T. Bright, A. Branson, J. Clamp, J. Gibson and the rest of the shark team and the staff of the Glover's Reef Research Station for their contributions to the elasmobranch sampling program. Special thanks go to Norlan, Faigon, Danny, Cardinal, Buck and Mervin, our Belizean boat captains, whose tireless efforts, fishing prowess and exhaustive knowledge of Glover's Reef made this study possible. This is publication number 24 of the Middle Caye Research Station.

\section{LITERATURE CITED}

Acosta CA (2001) Assessment of the functional effects of a harvest refuge on spiny lobster and queen conch populations at Glover's Reef, Belize. Proc Gulf Caribb Fish Inst 52:212-221

Acosta CA (2002) Spatially explicit dispersal dynamics and equilibrium population sizes in marine harvest refuges. ICES J Mar Sci 59:458-468

Acosta CA, Robertson DN (2003) Comparative spatial ecology of fished spiny lobsters Panulirus argus and an unfished congener $P$. guttatus in an isolated marine reserve at Glover's Reef Atoll, Belize. Coral Reefs 22:1-9

Bascompte J, Melián CJ, Sala E (2005) Interaction strength combinations and the overfishing of a marine food web. Proc Natl Acad Sci USA 102(15):5443-5447

Bonfil R (1997) Status of shark resources in the Southern Gulf of Mexico and Caribbean: implications for management. Fish Res 29:101-117

Brum JMM, Azevedo JMN (1995) First record of the Galapagos shark Carcharhinus galapagensis (Snodgrass \& Heller 1905) (Carcharhinidae) on the Azores. Bol Mus Munic Funchal A 4:139-143

Camhi M (1998) Sharks on the line: a state-by-state analysis of sharks and their fisheries. Living Oceans Program, National Audobon Society, Islip, NY

Carwardine M, Watterson K (2002) The shark watchers handbook: a guide to sharks and where to see them. Princeton University Press, Princeton, NJ

Castro JI (1993) The shark nursery of Bulls Bay, South Carolina, with a review of the shark nurseries of the southeastern coast of the United States. Environ Biol Fish 38: $37-48$

Castro JI (2000) The biology of the nurse shark, Ginglymostoma cirratum, off the Florida east coast and the Bahama Islands. Environ Biol Fish 158:1-22

Chapman DD, Abercrombie DL, Douady CJ, Pikitch EK, Stanhope MJ, Shivji MS (2003) A streamlined, biorganelle, multiplex PCR approach to species identification: application to global conservation and trade monitor- ing of the great white shark, Carcharodon carcharias. Conserv Genetics 4:415-425

Chapman DD, Pikitch EK, Babcock EA, Shivji MS (2005) Marine reserve design and evaluation using automated acoustic telemetry: a case-study involving coral reef-associated sharks in the Mesoamerican Caribbean. Mar Technol Soc J 39:40-53

Compagno LJV (1984) FAO species catalogue, Vol 4. Sharks of the world. An annotated and illustrated catalogue of shark species known to date. Part 2. Carcharhiniformes. FAO Fish Synop 125:251-655

Feldheim AK, Gruber SH, Ashley VM (2001) Population genetic structure of the lemon shark (Negaprion brevirostris) in the western Atlantic: DNA microsatellite variation. Mol Ecol 10:295-303

Gibson J (2003) Glover's Reef Marine Reserve \& World Heritage Site Management Plan. Commissioned by the Coastal Zone Management Authority and Institute (CZMAI) on behalf of the Fisheries Department. Belize City, Belize. CZMAI, Belize City

Gibson J, McField M, Heyman W, Wells S, Carter J, Sedberry G (2004) Belize's evolving system of marine reserves. In: Sobel J, Dahlgren C (eds) Marine reserves: a guide to science, design and use. Island Press, Washington, DC

Gruber SH, Nelson DR, Morrissey JF (1988) Patterns of activity and space utilization of lemon sharks, Negaprion brevirostris, in a shallow Bahamian lagoon. Bull Mar Sci 43: 61-76

Heithaus MR (2004) Predator-prey interactions. In: Carrier JC, Musick JA, Heithaus MR (eds) Biology of sharks and their relatives. CRC Press, Boca Raton, FL, p 487-523

Heithaus MR, Dill LM, Marshall GJ, Buhleier B (2002) Habitat use and foraging behavior of tiger sharks (Galeocerdo cuvier) in a seagrass ecosystem. Mar Biol 140:237-248

Henningsen AD (2000) Notes on reproduction in the southern stingray, Dasyatis americana (Chondrichthyes: Dasyatidae), in a captive environment. Copeia 2000:826-828

Heupel MR, Hueter RE (2002) Importance of prey density in relation to the movement patterns of juvenile blacktip sharks (Carcharhinus limbatus) within a coastal nursery area. Mar Freshw Res 53:543-550

Heyman WD, Graham RT, Kjerfve B, Johannes RE (2001) Whale sharks Rhincodon typus aggregate to feed on fish spawn in Belize. Mar Ecol Prog Ser 215:275-282

Huberty CJ, Petoskey MD (2000) Multivariate analysis of variance and covariance. In: Tinsley HEA, Brown SD (eds) Handbook of applied multivariate statistics and mathematical modeling. Academic Press, San Diego, CA, p 183-208

Johnson RH (1978) Sharks of Polynesia. Editions du Pacifique, Paeete, Tahiti

McClanahan TR, Sala E, Stickels PA, Cokos BA, Baker AC, Starger CJ, Jones SH IV (2003) Interaction between nutrients and herbivory in controlling algal communities and coral condition on Glover's Reef, Belize. Mar Ecol Prog Ser 261:135-147

McKibben JN, Nelson DR (1986) Patterns of movement and grouping of gray reef sharks, Carcharhinus amblyrhynchos, at Enewetak, Marshall Islands. Bull Mar Sci 38:89-110

Merson RR, Pratt HL Jr (2001) Distribution, movements and growth of young sandbar sharks, Carcharhinus plumbeus, in the nursery grounds of Delaware Bay. Environ Biol Fish 61:13-24

Morrissey JF, Gruber SH (1993) Habitat selection by juvenile lemon sharks, Negaprion brevirostris. Environ Biol Fish 38:311-319

Pank M, Stanhope M, Natanson L, Kohler N, Shivji M (2001) 
Rapid and simultaneous identification of body parts from the morphologically similar sharks Carcharhinus obscurus and Carcharhinus plumbeus (Carcharhinidae) using multiplex PCR. Mar Biotechnol 3:231-240

Shivji M, Clarke S, Pank M, Natanson L, Kohler N, Stanhope M (2002) Genetic identification of pelagic shark body parts for conservation and trade monitoring. Conserv Biol 16:1036-1047

Simpfendorfer CA, Heupel (2004) Assessing habitat use and movement. In: Carrier JC, Musick JA, Heithaus MR (eds) Biology of sharks and their relatives. CRC Press, Boca Raton, FL, p 553-573

Simpfendorfer CA, Milward NE (1993) Utilization of a tropical bay as a nursery area by sharks of the families Carcharhinidae and Sphyrnidae. Environ Biol Fish 37:337-345

Springer S (1967) Social organization of shark populations. In: Gilbert PW, Mathewson RF, Rall DP (eds) Sharks, skates and rays. Johns Hopkins Press, Baltimore, MD, p 149-174

Editorial responsibility: Otto Kinne (Editor-in-Chief), Oldendorf/Luhe, Germany
Stevens JD, Bonfil R, Dulvy NK, Walker PA (2000) The effects of fishing on sharks, rays and chimeras (chondrichthyans), and the implications for marine ecosystems. ICES J Mar Sci 57:476-494

Taniuchi T, Tachikawa H, Kurata Y, Nose Y (1985) Galapagos shark, Carcharhinus galapagensis, from the Ogasawara Islands, Japan. Jpn J Ichthyol 31:449-452

Tricas TC (1987) Shark ecology. In: Stevens J (ed) Sharks - an illustrated encyclopedic survey by international experts. Intercontinental Publishing Corporation, Hong Kong, p 96-101

Wetherbee BM, Crow GL, Lowe CG (1996) Biology of the Galapagos shark, Carcharhinus galapagensis, in Hawai'i. Environ Biol Fish 45:299-310

Wetherbee BM, Crow GL, Lowe CG (1997) Distribution, reproduction and diet of the gray reef shark Carcharhinus amblyrhynchos in Hawaii. Mar Ecol Prog Ser 151: 181-189

Submitted: December 9, 2004; Accepted: May 16, 2005

Proofs received from author(s): October 17, 2005 